\title{
B7-H3 and Its Role in Antitumor Immunity
}

\author{
Martin Loos, Dennis M. Hedderich, Helmut Friess, and Jörg Kleeff \\ Chirurgische Klinik und Poliklinik, Klinikum Rechts der Isar, Technische Universität München, Ismaninger Straße 22, \\ 81675 München, Germany
}

Correspondence should be addressed to Jörg Kleeff, kleeff@chir.med.tu-muenchen.de

Received 29 June 2010; Revised 16 September 2010; Accepted 19 October 2010

Academic Editor: C. D. Pauza

Copyright ( $) 2010$ Martin Loos et al. This is an open access article distributed under the Creative Commons Attribution License, which permits unrestricted use, distribution, and reproduction in any medium, provided the original work is properly cited.

B7-H3 is one of the most recently identified members of the B7/CD28 superfamily of costimulatory molecules serving as an accessory modulator of T-cell response. Recently, B7-H3 expression has been reported in several human cancers indicating an additional function of B7-H3 as a regulator of antitumor immunity. However, its precise physiologic role is still elusive, because both stimulatory and inhibitory capacities have been demonstrated. This paper summarizes the available data on B7-H3 in the regulation of T-cell response focusing on its potential role in antitumor immunity.

\section{Introduction}

T lymphocytes of the adaptive immune system are able to recognize and specifically respond to an incredible variety of foreign and native antigens. To ensure an appropriate Tcell response, which is essential to eradicate pathogens and to maintain self-tolerance, T-cell activation is finely tuned by two independent signaling pathways. The first signal requires recognition of the antigen-bearing major histocompatibility complex (MHC) on the surface of antigen-presenting cells (APCs) by the corresponding antigen-specific T-cell receptor (TCR) on T-cells. The second signal, which is antigen independent, is delivered by costimulatory molecules of the B7/CD28 family. B7-1/B7-2:CD28/CTLA-4 signaling represents the best characterized costimulatory pathway [1]. Engagement of B7-1 on APCs with CD28 on T-cells enhances T-cell proliferation and IL-2 production. In the absence of this simultaneous costimulatory signal, ligation of the TCR by an antigenic peptide results in T-cell dysfunction, intolerance or anergy. Apart from stimulatory signals that augment and sustain T-cell responses, costimulatory pathways also deliver inhibitory signals that downregulate or terminate Tcell responses [2]. Binding of CTLA-4 to B7-1 and/or B7-2 inhibits IL-2 synthesis and progression through the cell cycle leading to the termination of T-cell response. Within the past two decades, new costimulatory ligands and receptors have been identified, including B7-H1 (programmed death-1 ligand-1), B7-DC (programmed death-1 ligand-2), PD1 (programmed death-1), ICOS (inducible costimulator), ICOSL (ICOS-ligand), BTLA (B and T lymphocyte attenuator), $\mathrm{B} 7-\mathrm{H} 3$, and $\mathrm{B} 7-\mathrm{H} 4$ [3].

Recently, these previously identified B7 homologues have been implicated as potential regulators of antitumor immunity. For example, aberrant B7-H1 expression by cancer cells has been associated with adverse pathologic features and poor outcome in different human malignancies and has therefore been postulated as a potential mechanism by which malignant tumors may evade host immune response [4-8]. Taking advantage of manipulation of costimulatory signaling by cancer cells is comprehensible as T-cells play an important role in antitumor immunity. Under normal conditions, APCs that scavenge tumor cell debris and migrate to lymphoid tissues can interact with $\mathrm{CD} 4^{+}$and $\mathrm{CD} 8^{+} \mathrm{T}$-cells to induce activation of T-cells capable of recognizing tumor-specific or tumor-associated antigens. Thus, downregulation of tumorspecific T-cell responses by abusing inhibitory signaling pathways with induction of T-cell anergy or apoptosis through aberrant tumor B7-H1 expression may represent a possible immune escape mechanism. Hence, immunebased therapies which eliminate inhibitory T-cell signaling may represent a potent new approach for the treatment of human malignancies. Indeed, several phase I/II trials using humanized monoclonal antibodies (mAbs) to block CTLA-4 signaling have shown promising results in different human 
cancers [9-12]. These studies provide evidence that treatment with anti-CTLA- 4 mAbs is generally well tolerated and capable of inducing objective tumor responses in patients with prostate cancer, renal cell carcinoma, melanoma, and lymphoma [13-17].

$\mathrm{B} 7-\mathrm{H} 3$ is another recently identified costimulatory molecule that has been implicated as a potential regulator of antitumor response. However, its role in the regulation of T-cell response and in antitumor immunity remains controversial. This paper summarizes the existing data on the immunological function of $\mathrm{B} 7-\mathrm{H} 3$ and focuses on the potential role of B7-H3 in antitumor immunity.

\section{B7-H3}

2.1. Structure and Expression Pattern. B7-H3, identified in 2001 , is a type I transmembrane protein that shares $20 \%-$ $27 \%$ amino acid identity with other B7 family members [18]. Among the B7 family members, $\mathrm{B} 7-\mathrm{H} 3$ is the most conserved one with $\sim 88 \%$ amino acid identity between mice and humans. While murine B7-H3 consists of a single extracellular variable-type immunoglobulin (Ig)V-IgC domain and a signature intracellular domain (2Ig B7-H3), human B7-H3 possesses an additional isoform, the so-called 4Ig B7-H3 that contains a nearly exact tandem duplication of the IgV-IgC domain $[19,20]$. The $4 \mathrm{Ig}$ transcript is the dominant form in human tissues. So far, only one potential receptor of murine $\mathrm{B} 7-\mathrm{H} 3$ called triggering receptor expressed on myeloid cells (TREM-) like transcript 2 (TLT-2) has been identified. TLT-2 belongs to the TREM receptor family [21]. These receptors function as modulators of cellular responses and play important roles in both innate and adaptive immunities [22]. TLT-2 protein expression has been shown on $\mathrm{CD} 8^{+}$ T-cells constitutively and is induced on activated $\mathrm{CD} 4^{+} \mathrm{T}$ cells. Hashiguchi et al. recently found that binding of murine B7-H3 to TLT- 2 especially on CD8 ${ }^{+}$T-cells enhances T-cell effector functions such as proliferation, cytokine production, and cytotoxicity. Blockade of the TLT-2:B7-H3 pathway by mAbs against B7-H3 or TLT-2 effectively inhibited both the induction and effector phases of the contact hypersensitivity responses. Although these in vitro data investigating the interaction of murine B7-H3 with TLT-2 suggest that TLT2 might function as a receptor for B7-H3, Leitner and colleagues did not find evidence for such an interaction in both mice and humans [23]. As an accessory costimulatory molecule, B7-H3 protein is not constitutively expressed on T-cells, natural killer (NK) cells, and APCs, but its expression can be induced on these cell types. In contrast to B7-1 and B7-2 whose expressions are mainly limited to immune cells such as APCs, B7-H3 protein is found on osteoblasts, fibroblasts, fibroblast-like synoviocytes, and epithelial cells as well as in human liver, lung, bladder, testis, prostate, breast, placenta, and lymphoid organs. This broad expression pattern suggests more diverse immunological and probably nonimmunological functions of $\mathrm{B} 7-\mathrm{H} 3$, especially in peripheral tissues. Recently, B7-H3 expression has also been found in a variety of different human cancers, including prostate cancer, clear cell renal cell carcinoma (ccRCC), non-small-cell lung cancer (NSCLC), pancreatic cancer, gastric cancer, ovarian cancer, colorectal cancer (CRC) and urothelial cell carcinoma [24-31]. Although these findings suggest a possible involvement of $\mathrm{B} 7-\mathrm{H} 3$ in the regulation of antitumor immunity, its exact role remains far from clear, because both stimulatory and inhibitory properties have been identified and both beneficial as well as adverse effects of $\mathrm{B} 7-\mathrm{H} 3$ expression in cancers have been reported.

2.2. Functional Studies. Initial work on the functional properties of B7-H3 showed a stimulatory effect of human B7-H3 on T-cells. In vitro, $\mathrm{B} 7-\mathrm{H} 3$ was able to increase proliferation of both $\mathrm{CD}^{+}$and $\mathrm{CD} 8^{+} \mathrm{T}$-cells, enhance the induction of cytotoxic T lymphocytes (CTLs), and selectively stimulate interferon-gamma (IFN- $\gamma$ ) production in the presence of anti-CD3 Abs to mimic the TCR signal [18]. By contrast, inclusion of antisense B7-H3 oligonucleotides decreased the expression of $\mathrm{B} 7-\mathrm{H} 3$ on dendritic cells (DCs) and inhibited IFN- $\gamma$ production by DC-stimulated allogeneic Tcells. Further functional data in support of a stimulatory effect of B7-H3 come from several in vivo studies. Cardiac allografts in treated B7-H3-/- mice showed markedly decreased productions of key cytokine, chemokine, and chemokine receptor mRNA transcripts as compared to wildtype controls [32]. Moreover, the incidence of chronic rejection in two different cardiac allograft models was also inhibited in B7-H3-/- mice as compared to wildtype recipients. In a mouse model of allergic asthma, administration of anti-B7-H3 mAbs significantly reduced airway hyperactivity and resulted in decreased production of Th2 cytokines (interleukin-4 (IL-4), IL-5, and IL-13) as compared with control IgG-treated mice [33]. Furthermore, transfection of B7-H3 into mouse P815 tumor cells that were inoculated into syngeneic DBA/2 mice resulted in complete tumor regression of about one-half of the tumors and amplification of tumor-specific CD8 ${ }^{+}$CTL response [34]. The authors concluded that $\mathrm{B} 7-\mathrm{H} 3$ transfection enhanced the immunogenicity of the inoculated tumor cells. Similarly, injection of a mouse B7-H3 pcDNA3 expression plasmid into EL-4 lymphomas led to complete regression of $50 \%$ of tumors or otherwise significantly slowed tumor growth [35]. B7-H3-driven antitumor immunity was mediated by $\mathrm{CD}^{+} \mathrm{T}$-cells and NK cells. In an orthotopic murine colon cancer model, treatment by intratumoral injection of an adenovirus expressing mouse B7-H3 (Ad-B7-H3-GFP) resulted in a reduction of tumor size compared to control animals [36]. In addition, the occurrence of secondary metastasis was significantly reduced. Ad-B7-H3-GFP-treated animals showed significantly higher frequencies of tumorspecific IFN $-\gamma$ producing $\mathrm{CD} 8^{+}$T-cells. Based on these mouse cancer models, tumor-associated $\mathrm{B} 7-\mathrm{H} 3$ seems to preferentially regulate $\mathrm{CD} 4$-independent induction of $\mathrm{CD} 8^{+}$ CTL responses. Further lines of evidence for a stimulatory effect of B7-H3 come from a murine hepatocellular carcinoma model. Intratumoral injection of B7-H3-expressing plasmids followed by vasostatin-expressing plasmid injection 24 hours later resulted in a complete eradication of subcutaneous H22 tumors [37]. Interestingly, neither B7-H3 nor 
vasostatin monotherapy was effective. In contrast to these findings, which strongly suggest a stimulatory effect of B7-H3 on T-cell responses and antitumor immunity, other groups have proposed opposite functions for B7-H3. In mice, B7-H3 protein inhibited T-cell activation and effector cytokine production [38]. Furthermore, an antagonistic mAb to B7-H3 enhanced T-cell proliferation in vitro and led to exacerbated experimental autoimmune encephalomyelitis (EAE) in vivo [39]. In B7-H3-/- mice, Th1-mediated hypersensitivity and onset of EAE were promoted, and treatment with a blocking anti-B7-H3 mAb exacerbated EAE [38]. In a murine model of experimental allergic conjunctivitis (EC), administration of anti-B7-H3 mAbs during the induction phase augmented the severity of Th2-mediated EC [40]. In a different study, DC-associated $\mathrm{B} 7-\mathrm{H} 3$ induced by $\mathrm{CD} 4{ }^{+} \mathrm{CD} 25^{+}$regulatory T-cells (Tregs) impaired T-cell stimulatory function in vivo [41]. Accordingly, B7-H3-/- mice developed EAE earlier as wild-type littermates. Moreover, B7-H3-I- mice developed more severe airway inflammation under conditions in which T helper cells differentiated toward Th1 rather than Th2. In a different in vitro study, B7-H3 inhibited T-cell proliferation of both $\mathrm{CD}^{+}$and $\mathrm{CD} 8^{+} \mathrm{T}$-cells mediated by $\mathrm{Ab}$ to $\mathrm{T}$-cell receptor or allogeneic APCs [38].

2.3. Retrospective Analyses. In accordance to its inconsistent immunologic function regarding the regulation of T-cell responses which was demonstrated by several in vitro and in vivo studies, the role of $\mathrm{B} 7-\mathrm{H} 3$ in human cancer remains far from clear.

Data in support of a possible stimulatory function of B7-H3 in T-cell and antitumor responses come from retrospective analyses in different human cancers. In gastric cancer, $58.8 \%$ of gastric cancer cells in a series of 102 patients have been shown to express $\mathrm{B} 7-\mathrm{H} 3$ in the cell membrane and cytoplasm [26]. Tumor B7-H3 expression positively correlated with survival time, infiltration depth, and tissue type. In pancreatic cancer, high tumor B7-H3 expression by cancer cells in 68 examined patients was significantly associated with prolonged patient survival after surgical resection and significantly correlated with the number of tumor-infiltrating $\mathrm{CD}^{+}$T-cells [25].

However, several studies in other human cancers correlating tumor $\mathrm{B} 7-\mathrm{H} 3$ expression with clinicopathological features do not concur with these findings. Tumor B7-H3 expression in 70 patients with NSCLC inversely correlated with the number of tumor-infiltrating lymphocytes (TILs) and significantly correlated with lymph node metastasis [24]. In a separate study, the level of circulating soluble B7H3 (sB7-H3) in patients with NSCLC was associated with higher tumor stage, tumor size, nodal metastasis, and distant metastasis [42]. In ccRCC, $17.4 \%$ of tumor cells and $95.1 \%$ of tumor vasculature in 743 examined patients expressed B7-H3. B7-H3 expression in either tumor cells or tumor vasculature was found to significantly associate with an increased risk of death from ccRCC [28]. In another clinical study, B7-H3 was found to be uniformly and aberrantly expressed in adenocarcinomas of the prostate $(n=338)$. Marked B7-H3 intensity, which was found in approximately
$20 \%$ of the examined specimens, was associated with a $>4$-fold increased risk of cancer progression after surgery [31]. Similar results were shown in another study that investigated $\mathrm{B} 7-\mathrm{H} 3$ expression in 823 patients with prostate cancer. Tumor B7-H3 expression was found in $93 \%$ of patients treated with radical prostatectomy [43]. Strong B7$\mathrm{H} 3$ expression in the resected specimens correlated with disease spread and poor outcome. In CRC, strong B7-H3 expression could be observed in $54.3 \%$ of 102 CRC patients. Higher B7-H3 expression positively correlated with a more advanced tumor grade and negatively correlated with the intensity of TILs [29]. Most recently, B7-H3 was found to be expressed in $93 \%$ of 103 examined ovarian borderline tumors and carcinomas. B7-H3 was also expressed in the endothelium of tumor-associated vasculature in $44 \%$ of patients. Carcinomas with B7-H3-positive tumor vasculature were associated with a significantly shorter survival time and a higher incidence of recurrence [27]. All relevant studies regarding the clinical significance of $\mathrm{B} 7-\mathrm{H} 3$ in human cancer are summarized in Table 1 [24-31, 43-47].

\subsection{Reasons for the Contrasting Immunomodulatory Effects} of B7-H3. Based on the latter experimental and clinical data, the role of $\mathrm{B} 7-\mathrm{H} 3$ in human cancer remains unclear. Several explanations for the seemingly conflicting data exist, including the possible existence of additional receptors for B7-H3. So far, only TLT-2 has been identified as a potential receptor for $\mathrm{B} 7-\mathrm{H} 3$ that seems to enhance T-cell effector function in mice [21]. However, B7-H3 might use another receptor besides TLT-2 for its inhibitory function. Furthermore, it has to be considered that most of the existing functional studies have been performed in mouse models and that data regarding the immunomodulatory effects of B7-H3 from these murine studies might not be transferable into humans. Evidence for differences between mouse and human B7-H3 includes the existence of varying isoforms. In mice, the predominant isoform of $\mathrm{B} 7-\mathrm{H} 3$ consists of a classical single extracellular IgV-IgC domain (2Ig B7-H3) whereas the predominant isoform in humans consists of a dual IgV-IgC domain (4Ig B7-H3). It is also conceivable that other additional isoforms may exist. Another possible explanation for the inconclusive data on the functional role of B7-H3 in antitumor response comprises the level of B7$\mathrm{H} 3$ expression on cancer cells that may be of relevance for the induction of different immunological functions. Based on its expression level, B7-H3 may interact with different affinities for several existing receptors and may therefore exert different functions. A similar functional discrepancy regarding the expression levels of a costimulatory molecule in cancer has been shown for B7-1 [48]. Because of inhibitory effects on immune response, low B7-1 expression on murine colon carcinoma cell lines has been implicated as a possible immune-escape mechanism for tumor cells, presumably through binding of the inhibitory T-cell receptor CTLA-4. By contrast, artificially enforced expression of B7-1 on these tumor cells resulted in a strong increase of immunogenicity. The authors of this study concluded that the different effect of B7-1 may be explained by the noticeable higher affinity of 
TABLE 1: Relevant clinical studies investigating the relationship between B7-H3 expression in human cancer tissues with clinicopathological features.

\begin{tabular}{|c|c|c|c|c|c|c|c|}
\hline \multirow{2}{*}{ Author } & \multirow{2}{*}{ Journal } & \multirow{2}{*}{ Year } & \multirow{2}{*}{$\begin{array}{l}\text { Type of } \\
\text { malignancy }\end{array}$} & \multirow{2}{*}{$\begin{array}{l}\text { Number of } \\
\text { patients }\end{array}$} & \multirow{2}{*}{$\begin{array}{l}\text { Positive } \\
\text { tumor- } \\
\text { associated } \\
\text { B7-H3 } \\
\text { expression }\end{array}$} & \multicolumn{2}{|c|}{ Correlation with clinicopathologic features } \\
\hline & & & & & & Favorable & Adverse \\
\hline $\begin{array}{l}\text { Sun et al. } \\
{[29]}\end{array}$ & $\begin{array}{l}\text { Cancer } \\
\text { Immunol } \\
\text { Immunother }\end{array}$ & 2010 & $\begin{array}{l}\text { Colorectal } \\
\text { cancer }\end{array}$ & 102 & $87.3 \%$ & - & $\begin{array}{l}\text { Higher tumor B7-H3 correlated } \\
\text { with a more advanced tumor grade }\end{array}$ \\
\hline \multirow[t]{2}{*}{$\begin{array}{l}\text { Zang et al. } \\
{[27]}\end{array}$} & Mod Pathol & 2010 & $\begin{array}{l}\text { Ovarian } \\
\text { carcinoma }\end{array}$ & 103 & $\begin{array}{l}93 \% \text { of tumor } \\
\text { cells }\end{array}$ & - & $\begin{array}{l}\text { Significant shorter survival time and } \\
\text { higher incidence of recurrence for } \\
\text { patients with positive B7-H3 tumor } \\
\text { vasculature }\end{array}$ \\
\hline & & & & & $\begin{array}{l}44 \% \text { of tumor } \\
\text { vasculature }\end{array}$ & & \multirow[b]{2}{*}{$\begin{array}{l}\text { Increased risk of biochemical } \\
\text { recurrence for patients with } \\
\text { moderate and marked B7-H3 } \\
\text { staining }\end{array}$} \\
\hline $\begin{array}{l}\text { Parker et } \\
\text { al. [46] }\end{array}$ & $\begin{array}{l}\text { Int J Radiat } \\
\text { Oncol Biol Phys }\end{array}$ & 2010 & $\begin{array}{l}\text { Recurrent } \\
\text { prostate cancer }\end{array}$ & 148 & $100 \%$ & - & \\
\hline $\begin{array}{l}\text { Loos et al. } \\
{[25]}\end{array}$ & BMC Cancer & 2009 & $\begin{array}{l}\text { Pancreatic } \\
\text { cancer }\end{array}$ & 68 & $88.2 \%$ & $\begin{array}{l}\text { high tumor } \\
\text { B7-H3 } \\
\text { expression was } \\
\text { associated with } \\
\text { significantly } \\
\text { better } \\
\text { postoperative } \\
\text { prognosis }\end{array}$ & - \\
\hline $\begin{array}{l}\text { Boorjian } \\
\text { et al. [44] }\end{array}$ & Urology & 2009 & $\begin{array}{l}\text { Renal angiomy- } \\
\text { olipoma/ } \\
\text { pulmonary } \\
\text { lymphangio- } \\
\text { leiomyomatosis }\end{array}$ & $110 / 7$ & $\begin{array}{l}100 \% \text { and } \\
2.7 \%\end{array}$ & - & - \\
\hline $\begin{array}{l}\text { Yamato } \\
\text { et al. [47] }\end{array}$ & Br J Cancer & 2009 & $\begin{array}{l}\text { Pancreatic } \\
\text { cancer }\end{array}$ & 59 & $93.2 \%$ & - & $\begin{array}{l}\text { Strong tumor } \mathrm{B} 7-\mathrm{H} 3 \text { expression was } \\
\text { significantly associated with lymph } \\
\text { node metastasis and advanced } \\
\text { pathological stage }\end{array}$ \\
\hline $\begin{array}{l}\text { Crispen } \\
\text { et al. [28] }\end{array}$ & Clin Cancer Res & 2008 & ccRCC & 743 & $\begin{array}{l}17 \% \text { of tumor } \\
\text { cells } \\
95 \% \text { of tumor } \\
\text { vasculature }\end{array}$ & - & $\begin{array}{l}\text { Either tumor cell or diffuse } \\
\text { tumor vasculature B7-H3 } \\
\text { expression was significantly } \\
\text { associated with an increased risk }\end{array}$ \\
\hline $\begin{array}{l}\text { Boorjian } \\
\text { et al. [30] }\end{array}$ & Clin Cancer Res & 2008 & $\begin{array}{l}\text { Urothelial cell } \\
\text { carcinoma }\end{array}$ & 318 & $70.7 \%$ & - & of death from ccRCC \\
\hline $\begin{array}{l}\text { Greorio } \\
\text { et al. [45] }\end{array}$ & Histopathology & 2008 & Neuroblastoma & 53 & $74 \%$ & - & $\begin{array}{l}\text { High tumor B7-H3 expression was } \\
\text { associated with a worse event-free } \\
\text { survival }\end{array}$ \\
\hline $\begin{array}{l}\text { Zang et al. } \\
{[43]}\end{array}$ & PNAS & 2007 & Prostate cancer & 823 & $93 \%$ & - & $\begin{array}{l}\text { Patients with strong tumor B7-H3 } \\
\text { expression were at significantly } \\
\text { increased risk of clinical cancer } \\
\text { recurrence and cancer-specific death }\end{array}$ \\
\hline $\begin{array}{l}\text { Roth et al. } \\
{[31]}\end{array}$ & Cancer Res & 2007 & Prostate cancer & 338 & $100 \%$ & - & $\begin{array}{l}\text { (1) Increasing levels of tumor } \\
\text { B7-H3 intensity correlated with } \\
\text { worsening clinicopathologic } \\
\text { features, including tumor volume, } \\
\text { extraprostatic extension, higher } \\
\text { Gleason score, seminal vesicle } \\
\text { involvement, surgical margins }\end{array}$ \\
\hline & & & & & & & $\begin{array}{l}\text { (2) Marked tumor B7-H3 intensity } \\
\text { was significantly associated with } \\
\text { cancer progression }\end{array}$ \\
\hline
\end{tabular}


Table 1: Continued.

\begin{tabular}{|c|c|c|c|c|c|c|c|}
\hline \multirow{2}{*}{ Author } & \multirow{2}{*}{ Journal } & \multirow{2}{*}{ Year } & \multirow{2}{*}{$\begin{array}{l}\text { Type of } \\
\text { malignancy }\end{array}$} & \multirow{2}{*}{$\begin{array}{l}\text { Number of } \\
\text { patients }\end{array}$} & \multirow{2}{*}{$\begin{array}{l}\text { Positive } \\
\text { tumor- } \\
\text { associated } \\
\text { B7-H3 } \\
\text { expression }\end{array}$} & \multicolumn{2}{|c|}{ Correlation with clinicopathologic features } \\
\hline & & & & & & Favorable & Adverse \\
\hline $\begin{array}{l}\text { Sun et al. } \\
{[24]}\end{array}$ & Lung Cancer & 2006 & NSCLC & 70 & $37.1 \%$ & - & $\begin{array}{l}\text { High tumor B7-H3 expression was } \\
\text { significantly more common in cases } \\
\text { with lymph node metastasis }\end{array}$ \\
\hline $\begin{array}{l}\text { Wu et al. } \\
{[26]}\end{array}$ & $\begin{array}{l}\text { World J } \\
\text { Gastroenterol }\end{array}$ & 2006 & Gastric cancer & 102 & $58.8 \%$ & $\begin{array}{l}\text { Positive tumor } \\
\text { B7-H3 } \\
\text { expression was } \\
\text { significantly } \\
\text { associated with } \\
\text { better } \\
\text { postoperative } \\
\text { survival }\end{array}$ & - \\
\hline
\end{tabular}

B7-1 for CTLA-4 which has been shown to be 100- to 1,000fold higher than for CD28. Apart from the possible existence of additional $\mathrm{B} 7-\mathrm{H} 3$ receptors, the definition of positive B7$\mathrm{H} 3$ expression and B7-H3 expression levels in the available studies was not standardized. In the study analyzing the role of B7-H3 in human gastric cancer, specimens were scored as B7-H3-expressing tumors when more than $20 \%$ of tumor cells stained positive for B7-H3 [26]. Sun et al. defined low tumor-B7-H3 expression in NSCLC when less than $10 \%$ of tumors expressed B7-H3 [24]. In this study, 37.1\% of the examined specimens expressed B7-H3. In ccRCC, tumors with less than $10 \%$ of cells stained positive were scored as having negative B7-H3 expression. 17\% of specimens revealed positive tumor cell B7-H3 expression [28]. Zang et al. did not define the difference between high or low tumor B7-H3 expression in prostate cancer at all [43]. In none of these studies, B7-H3 staining intensity was not taken into account. In our recent study, the most detailed scoring system was used for expression analysis of B7-H3 in pancreatic cancer. Scores were given separately for the stained area and for the intensity of staining [25]. In addition to the different definitions of positive B7-H3 expression and B7$\mathrm{H} 3$ expression levels that were used in previous retrospective studies, a possible influence of soluble forms of B7-H3 was not examined. Based on a study analyzing sB7-H3 levels in NSCLC that showed that the level of circulating sB7-H3 was associated with higher tumor stage, tumor size, nodal metastasis, and distant metastasis, one could speculate that sB7-H3 may also contribute to the modulation of immune response [42]. Another possible reason may include the expression of aberrant forms of B7-H3 on tumor cells which cannot be differentiated by the existing antibodies.Yi and Chen recently worried that many so-called "neutralizing antibodies" may not be just blocking antibodies but have other effects such as triggering the B7-H3 signal [49]. Furthermore, genetic polymorphisms in B7-H3 may modify T-cell responses in human cancers. Recent studies have shown that polymorphisms in the inhibitory molecule CTLA-4 alter cancer susceptibility through modification of
T-cell response [50]. Finally, B7-H3 may also affect other immune cells than T-cells. In neuroblastoma, 4Ig-B7-H3 molecules expressed at the tumor cell surface have been shown to exert a protective role from NK-mediated lysis by interacting with a still undefined inhibitory receptor expressed on NK cells [19].

2.5. Therapeutic Potential of B7-H3. Immune-based therapies which additionally stimulate T-cell activation or eliminate inhibitory T-cell signaling in order to enforce tumorreactive T-cell responses represent a potent new approach for the treatment of human malignancies. Blockade of the inhibitory receptor CTLA-4 by mAbs has been tested as a single agent or in combinations in patients with advanced cancer, including breast cancer, lymphoma, melanoma, ovarian cancer, prostate cancer, and ccRCC $[9,15,17,51-$ 54]. Most trials have not only shown that anti-CTLA-4 $\mathrm{mAb}$ treatment is safe but also provide evidence for its antitumor effects. In unresectable advanced melanoma for instance, durable tumor responses and disease control rates have been observed. PD-1 is another inhibitory receptor expressed on activated T-cells that may suppress antitumor immunity. Therefore, single-agent anti-PD-1 blockade has been tested in a Phase I trial of 39 patients with advanced metastatic melanoma, CRC, NSCLC, castrateresistant prostate cancer, and ccRCC. Anti-PD-1 treatment resulted in one durable complete response and two partial responses [55].

Given its immunomodulatory capacities, B7-H3 may also represent a new target in cancer treatment. In contrast to CTLA-4 and PD-1, however, one has to take into account that B7-H3 is more broadly expressed, especially in peripheral healthy tissues. Therefore, blockade of B7-H3 by mAbs or treatment with B7-H3 (i.e., by gene transfer) may be associated with severe adverse effects. Furthermore, the functional role of B7-H3 in antitumor immunity is not completely understood, and controversies regarding its stimulatory and inhibitory capacities remain to be elucidated. 


\section{Conclusions}

Within the past decade, new insights into immunomodulatory capacities of costimulatory signaling in antitumor response have opened the door for new potent approaches in cancer therapy. Recent clinical Phase I/II trials have provided solid evidence that treatment with anti-CTLA-4 mAbs is capable of inducing objective antitumor responses. B7-H3, a recently identified member of the B7/CD28 superfamily of costimulatory molecules, has been shown to play an important role in immune regulation. Although data on the precise role of $\mathrm{B} 7-\mathrm{H} 3$ in the regulation of $\mathrm{T}$-cell responses and especially in antitumor immunity has yet to be elucidated, B7-H3 represents a promising new target for immunebased antitumor therapies. The previous identification of the costimulatory receptor TLT-2 is the first significant step toward resolving the available conflicting data.

However, further work particularly concerned with the identification of inhibitory receptors for B7-H3 is ongoing.

\section{References}

[1] A. K. Abbas, "The control of T cell activation vs. tolerance," Autoimmunity Reviews, vol. 2, no. 3, pp. 115-118, 2003.

[2] L. Chen, "Co-inhibitory molecules of the B7-CD28 family in the control of T-cell immunity," Nature Reviews Immunology, vol. 4, no. 5, pp. 336-347, 2004.

[3] R. J. Greenwald, G. J. Freeman, and A. H. Sharpe, "The B7 family revisited," Annual Review of Immunology, vol. 23, pp. 515-548, 2005.

[4] M. Loos, N. A. Giese, J. Kleeff et al., "Clinical significance and regulation of the costimulatory molecule $\mathrm{B} 7-\mathrm{H} 1$ in pancreatic cancer," Cancer Letters, vol. 268, no. 1, pp. 98-109, 2008.

[5] J. Konishi, K. Yamazaki, M. Azuma, I. Kinoshita, H. DosakaAkita, and M. Nishimura, "B7-H1 expression on non-small cell lung cancer cells and its relationship with tumorinfiltrating lymphocytes and their PD-1 expression," Clinical Cancer Research, vol. 10, no. 15, pp. 5094-5100, 2004.

[6] Y. Liu, B. Zeng, Z. Zhang, Y. Zhang, and R. Yang, "B7-H1 on myeloid-derived suppressor cells in immune suppression by a mouse model of ovarian cancer," Clinical Immunology, vol. 129, no. 3, pp. 471-481, 2008.

[7] H. Ghebeh, S. Mohammed, A. Al-Omair et al., "The B7H1 (PD-L1) T lymphocyte-inhibitory molecule is expressed in breast cancer patients with infiltrating ductal carcinoma: correlation with important high-risk prognostic factors," Neoplasia, vol. 8, no. 3, pp. 190-198, 2006.

[8] R. H. Thompson, M. D. Gillett, J. C. Cheville et al., "Costimulatory B7-H1 in renal cell carcinoma patients: indicator of tumor aggressiveness and potential therapeutic target," Proceedings of the National Academy of Sciences of the United States of America, vol. 101, no. 49, pp. 17174-17179, 2004.

[9] E. J. Small, N. S. Tchekmedyian, B. I. Rini, L. Fong, I. Lowy, and J. P. Allison, "A pilot trial of CTLA-4 blockade with human anti-CTLA-4 in patients with hormone-refractory prostate cancer," Clinical Cancer Research, vol. 13, no. 6, pp. 1810-1815, 2007.

[10] E. D. Kwon, B. A. Foster, A. A. Hurwitz et al., "Elimination of residual metastatic prostate cancer after surgery and adjunctive cytotoxic $\mathrm{T}$ lymphocyte-associated antigen 4 (CTLA4) blockade immunotherapy," Proceedings of the National
Academy of Sciences of the United States of America, vol. 96, no. 26, pp. 15074-15079, 1999.

[11] M. R. Theoret, P. M. Arlen, M. Pazdur, W. L. Dahut, J. Schlom, and J. L. Gulley, "Phase I trial of an enhanced prostatespecific antigen-based vaccine and anti-CTLA-4 antibody in patients with metastatic androgen-independent prostate cancer," Clinical Genitourinary Cancer, vol. 5, no. 5, pp. 347350, 2007.

[12] C. I. Liakou, A. Kamat, D. N. Tang et al., "CTLA-4 blockade increases IFN $\gamma$-producing CD4+ICOS hi cells to shift the ratio of effector to regulatory T cells in cancer patients," Proceedings of the National Academy of Sciences of the United States of America, vol. 105, no. 39, pp. 14987-14992, 2008.

[13] R. H. Thompson, J. P. Allison, and E. D. Kwon, "Anti-cytotoxic T lymphocyte antigen-4 (CTLA-4) immunotherapy for the treatment of prostate cancer," Urologic Oncology, vol. 24, no. 5, pp. 442-447, 2006.

[14] J. A. Blansfield, K. E. Beck, K. Tran et al., "Cytotoxic T-lymphocyte-associated antigen- 4 blockage can induce autoimmune hypophysitis in patients with metastatic melanoma and renal cancer," Journal of Immunotherapy, vol. 28, no. 6, pp. 593-598, 2005.

[15] J. Yuan, S. Gnjatic, H. Li et al., "CTLA-4 blockade enhances polyfunctional NY-ESO-1 specific T cell responses in metastatic melanoma patients with clinical benefit," Proceedings of the National Academy of Sciences of the United States of America, vol. 105, no. 51, pp. 20410-20415, 2008.

[16] D. O'Mahony, J. C. Morris, C. Quinn et al., "A pilot study of CTLA-4 blockade after cancer vaccine failure in patients with advanced malignancy," Clinical Cancer Research, vol. 13, no. 3 , pp. 958-964, 2007.

[17] S. M. Ansell, S. A. Hurvitz, P. A. Koenig et al., "Phase I study of ipilimumab, an anti-CTLA-4 monoclonal antibody, in patients with relapsed and refractory B-cell non-Hodgkin lymphoma," Clinical Cancer Research, vol. 15, no. 20, pp. 6446-6453, 2009.

[18] A. I. Chapoval, J. Ni, J. S. Lau et al., "B7-H3: a costimulatory molecule for T cell activation and IFN- $\gamma$ production," Nature Immunology, vol. 2, no. 3, pp. 269-274, 2001.

[19] R. Castriconi, A. Dondero, R. Augugliaro et al., "Identification of 4Ig-B7-H3 as a neuroblastoma-associated molecule that exerts a protective role from an NK cell-mediated lysis," Proceedings of the National Academy of Sciences of the United States of America, vol. 101, no. 34, pp. 12640-12645, 2004.

[20] P. Steinberger, O. Majdic, S. V. Derdak et al., "Molecular characterization of human 4Ig-B7-H3, a member of the B7 family with four Ig-like domains," Journal of Immunology, vol. 172, no. 4, pp. 2352-2359, 2004.

[21] M. Hashiguchi, H. Kobori, P. Ritprajak, Y. Kamimura, H. Kozono, and M. Azuma, "Triggering receptor expressed on myeloid cell-like transcript 2 (TLT-2) is a counter-receptor for $\mathrm{B} 7-\mathrm{H} 3$ and enhances T cell responses," Proceedings of the National Academy of Sciences of the United States of America, vol. 105, no. 30, pp. 10495-10500, 2008.

[22] J. Klesney-Tait, I. R. Turnbull, and M. Colonna, "The TREM receptor family and signal integration," Nature Immunology, vol. 7, no. 12, pp. 1266-1273, 2006.

[23] J. Leitner, C. Klauser, W. F. Pickl et al., "B7-H3 is a potent inhibitor of human T-cell activation: no evidence for B7-H3 and TREML2 interaction," European Journal of Immunology, vol. 39, no. 7, pp. 1754-1764, 2009.

[24] Y. Sun, Y. Wang, J. Zhao et al., "B7-H3 and B7-H4 expression in non-small-cell lung cancer," Lung Cancer, vol. 53, no. 2, pp. 143-151, 2006. 
[25] M. Loos, D. M. Hedderich, M. Ottenhausen et al., "Expression of the costimulatory molecule B7-H3 is associated with prolonged survival in human pancreatic cancer," BMC Cancer, vol. 9, article 463, 2009.

[26] X.-P. Wu, J.-T. Jiang, M. Tan et al., "Relationship between costimulatory molecue $\mathrm{B} 7-\mathrm{H} 3$ expression and gastric carcinoma histology and prognosis," World Journal of Gastroenterology, vol. 12, no. 3, pp. 457-459, 2006.

[27] X. Zang, P. S. Sullivan, R. A. Soslow et al., "Tumor associated endothelial expression of B7-H3 predicts survival in ovarian carcinomas," Modern Pathology, vol. 23, no. 8, pp. 1104-1112, 2010.

[28] P. L. Crispen, Y. Sheinin, T. J. Roth et al., "Tumor cell and tumor vasculature expression of $\mathrm{B} 7-\mathrm{H} 3$ predict survival in clear cell renal cell carcinoma," Clinical Cancer Research, vol. 14, no. 16, pp. 5150-5157, 2008.

[29] J. Sun, L. -J. Chen, G. -B. Zhang et al., "Clinical significance and regulation of the costimulatory molecule B7-H3 in human colorectal carcinoma," Cancer Immunology, Immunotherapy, vol. 59, no. 8, pp. 1163-1171, 2010.

[30] S. A. Boorjian, Y. Sheinin, P. L. Crispen et al., "T-Cell coregulatory molecule expression in urothelial cell carcinoma: clinicopathologic correlations and association with survival," Clinical Cancer Research, vol. 14, no. 15, pp. 4800-4808, 2008.

[31] T. J. Roth, Y. Sheinin, C. M. Lohse et al., "B7-H3 ligand expression by prostate cancer: a novel marker of prognosis and potential target for therapy," Cancer Research, vol. 67, no. 16, pp. 7893-7900, 2007.

[32] L. Wang, C. C. Fraser, K. Kikly et al., "B7-H3 promotes acute and chronic allograft rejection,” European Journal of Immunology, vol. 35, no. 2, pp. 428-438, 2005.

[33] O. Nagashima, N. Harada, Y. Usui et al., "B7-H3 contributes to the development of pathogenic Th2 cells in a murine model of asthma," Journal of Immunology, vol. 181, no. 6, pp. 40624071, 2008.

[34] L. Luo, A. I. Chapoval, D. B. Flies et al., "B7-H3 enhances tumor immunity in vivo by costimulating rapid clonal expansion of antigen-specific CD8+ cytolytic T cells," Journal of Immunology, vol. 173, no. 9, pp. 5445-5450, 2004.

[35] X. Sun, M. Vale, E. Leung, J. R. Kanwar, R. Gupta, and G. W. Krissansen, "Mouse B7-H3 induces antitumor immunity," Gene Therapy, vol. 10, no. 20, pp. 1728-1734, 2003.

[36] C. M. Lupu, C. Eisenbach, A. D. Lupu et al., "Adenoviral B7$\mathrm{H} 3$ therapy induces tumor specific immune responses and reduces secondary metastasis in a murine model of colon cancer," Oncology reports, vol. 18, no. 3, pp. 745-748, 2007.

[37] L. Ma, L. Luo, H. Qiao et al., "Complete eradication of hepatocellular carcinomas by combined vasostatin gene therapy and B7H3-mediated immunotherapy," Journal of Hepatology, vol. 46, no. 1, pp. 98-106, 2007.

[38] W.-K. Suh, B. U. Gajewska, H. Okada et al., "The B7 family member B7-H3 preferentially down-regulates T helper type 1mediated immune responses," Nature Immunology, vol. 4, no. 9, pp. 899-906, 2003.

[39] D. V. R. Prasad, T. Nguyen, Z. Li et al., "Murine B7-H3 is a negative regulator of T cells," Journal of Immunology, vol. 173, no. 4, pp. 2500-2506, 2004.

[40] A. Fukushima, T. Sumi, K. Fukuda et al., "B7-H3 regulates the development of experimental allergic conjunctivitis in mice," Immunology Letters, vol. 113, no. 1, pp. 52-57, 2007.

[41] K. Mahnke, S. Ring, T. S. Johnson et al., "Induction of immunosuppressive functions of dendritic cells in vivo by $\mathrm{CD} 4+\mathrm{CD} 25+$ regulatory T cells: role of B7-H3 expression and antigen presentation," European Journal of Immunology, vol. 37, no. 8, pp. 2117-2126, 2007.

[42] G. Zhang, Y. Xu, X. Lu et al., "Diagnosis value of serum B7-H3 expression in non-small cell lung cancer," Lung Cancer, vol. 66, no. 2, pp. 245-249, 2009.

[43] X. Zang, R. H. Thompson, H. A. Al-Ahmadie et al., "B7-H3 and $\mathrm{B} 7 \mathrm{x}$ are highly expressed in human prostate cancer and associated with disease spread and poor outcome," Proceedings of the National Academy of Sciences of the United States of America, vol. 104, no. 49, pp. 19458-19463, 2007.

[44] S. A. Boorjian, Y. Sheinin, P. L. Crispen, C. M. Lohse, B. C. Leibovich, and E. D. Kwon, "T-cell co-regulatory molecule expression in renal angiomyolipoma and pulmonary lymphangioleiomyomatosis," Urology, vol. 74, no. 6, pp. 13591364, 2009.

[45] A. Gregorio, M. V. Corrias, R. Castriconi et al., "Small round blue cell tumours: diagnostic and prognostic usefulness of the expression of B7-H3 surface molecule," Histopathology, vol. 53, no. 1, pp. 73-80, 2008.

[46] A. S. Parker, M. G. Heckman, Y. Sheinin et al., "Evaluation of B7-H3 expression as a biomarker of biochemical recurrence after salvage radiation therapy for recurrent prostate cancer," International Journal of Radiation Oncology, Biology, Physics. In press.

[47] I. Yamato, M. Sho, T. Nomi et al., "Clinical importance of B7H3 expression in human pancreatic cancer," British Journal of Cancer, vol. 101, no. 10, pp. 1709-1716, 2009.

[48] I. Tirapu, E. Huarte, C. Guiducci et al., "Low surface expression of B7-1 (CD80) is an immunoescape mechanism of colon carcinoma," Cancer Research, vol. 66, no. 4, pp. 24422450, 2006.

[49] K. H. Yi and L. Chen, "Fine tuning the immune response through B7-H3 and B7-H4," Immunological Reviews, vol. 229, no. 1, pp. 145-151, 2009.

[50] T. Sun, Z. Hu, H. Shen, and D. Lin, "Genetic polymorphisms in cytotoxic T-lymphocyte antigen 4 and cancer: the dialectical nature of subtle human immune dysregulation," Cancer Research, vol. 69, no. 15, pp. 6011-6014, 2009.

[51] M. Z. Dewan, A. E. Galloway, N. Kawashima et al., "Fractionated but not single-dose radiotherapy induces an immunemediated abscopal effect when combined with anti-CTLA-4 antibody," Clinical Cancer Research, vol. 15, no. 17, pp. 53795388, 2009.

[52] A. V. Maker, G. Q. Phan, P. Attia et al., "Tumor regression and autoimmunity in patients treated with cytotoxic $\mathrm{T}$ lymphocyte-associated antigen 4 blockade and interleukin 2: a phase I/II study," Annals of Surgical Oncology, vol. 12, no. 12, pp. 1005-1016, 2005.

[53] F. S. Hodi, M. C. Mihm, R. J. Soiffer et al., "Biologic activity of cytotoxic $\mathrm{T}$ lymphocyte-associated antigen 4 antibody blockade in previously vaccinated metastatic melanoma and ovarian carcinoma patients," Proceedings of the National Academy of Sciences of the United States of America, vol. 100, no. 8, pp. 4712-4717, 2003.

[54] H. J. J. van der Vliet, H. B. Koon, S. C. Yue et al., "Effects of the administration of high-dose interleukin-2 on immunoregulatory cell subsets in patients with advanced melanoma and renal cell cancer," Clinical Cancer Research, vol. 13, no. 7, pp. 2100-2108, 2007.

[55] J. R. Brahmer, C. G. Drake, I. Wollner et al., "Phase I study of single-agent anti-programmed death-1 (MDX-1106) in refractory solid tumors: safety, clinical activity, pharmacodynamics, and immunologic correlates," Journal of Clinical Oncology, vol. 28, no. 19, pp. 3167-3175, 2010. 


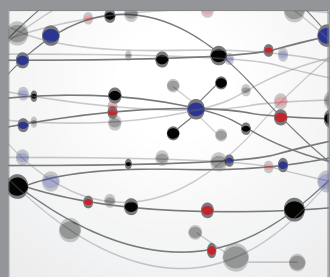

The Scientific World Journal
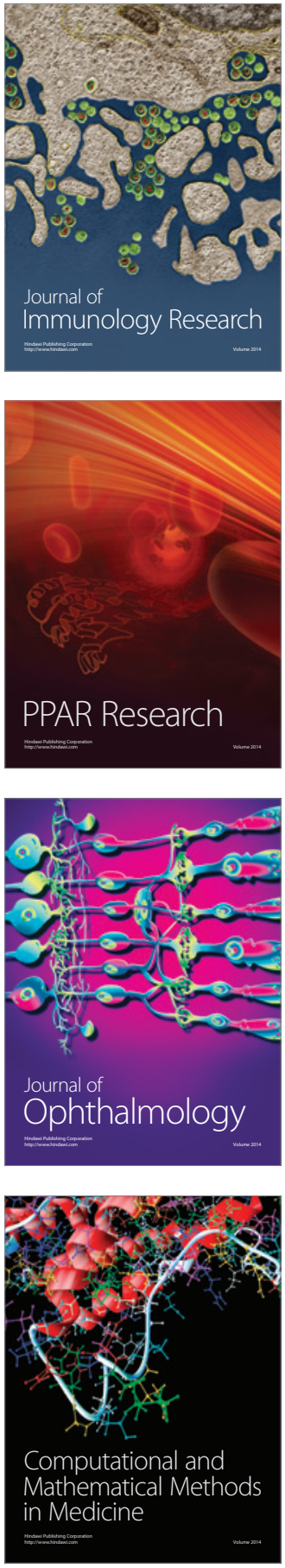

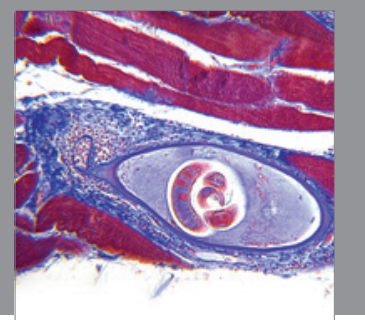

Gastroenterology

Research and Practice
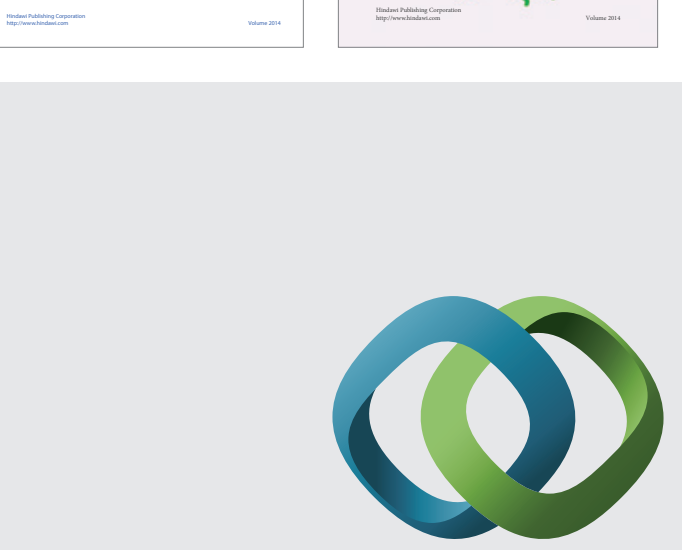

\section{Hindawi}

Submit your manuscripts at

http://www.hindawi.com
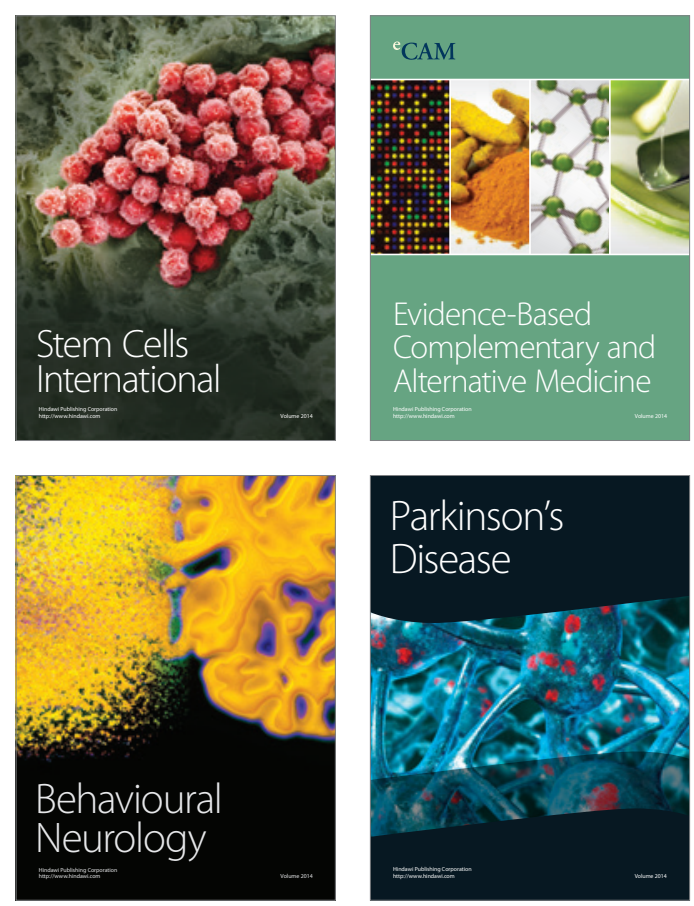

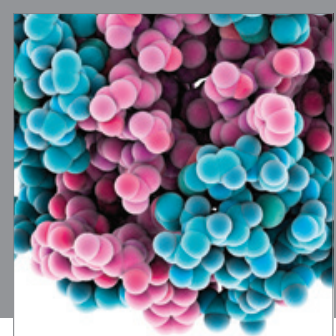

Journal of
Diabetes Research

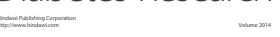

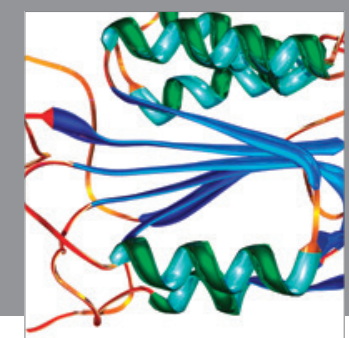

Disease Markers
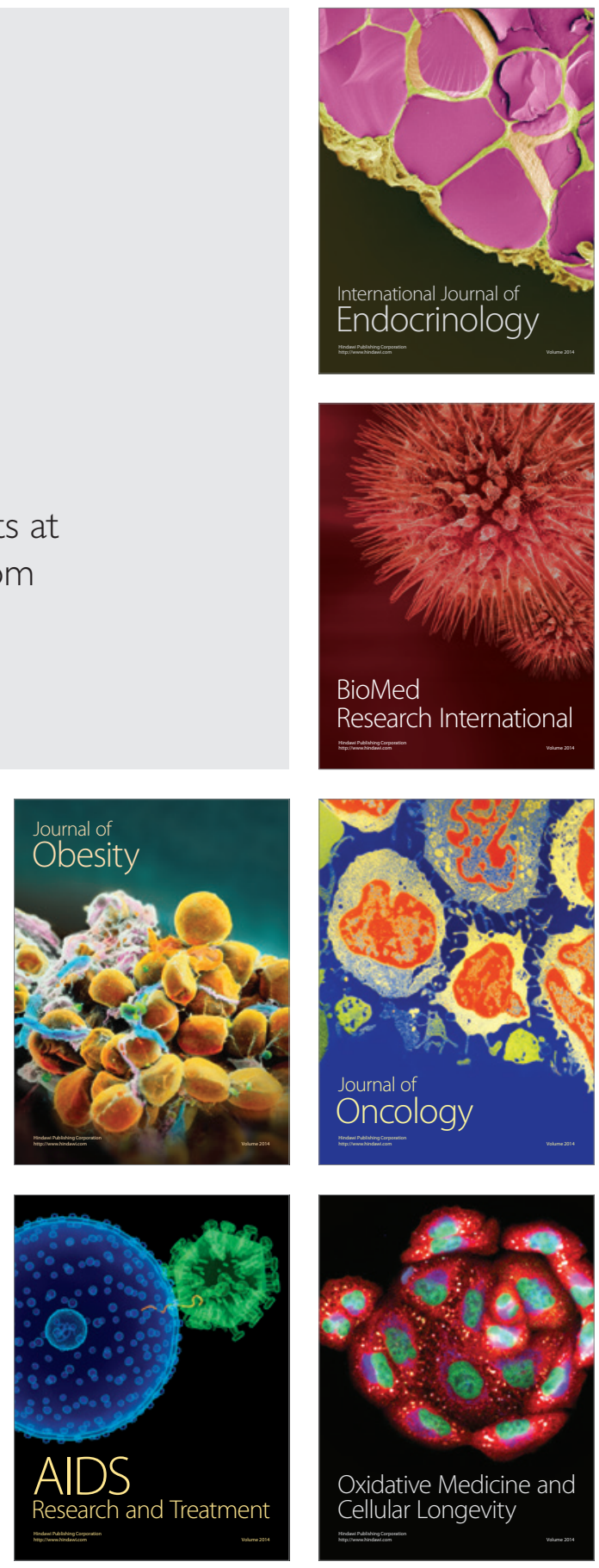